\title{
In-Situ Mineralogical Analysis of the Venus Surface using X-ray Diffraction
}

\author{
Authors: D.F. Blake ${ }^{1}$, T. F. Bristow ${ }^{1}$, P. Sarrazin ${ }^{2}$, and K. Zacny ${ }^{3}$ \\ ${ }^{1}$ Exobiology Branch, MS 239-4, NASA Ames Research Center, Moffett Field, CA 94035 \\ (david.blake@nasa.gov); ${ }^{2}$ SETI Institute, Mountain View, CA; ${ }^{3}$ Honeybee Robotics, Pasadena, \\ CA. \\ Sponsors: C. N. Achilles ${ }^{3}$, N. Castle ${ }^{4}$, S. J. Chipera ${ }^{5}$, P. I. Craig 4 , D. J. Des Marais ${ }^{6}$, R. T. Downs ${ }^{7}$, \\ R. M. Hazen ${ }^{8}$, B. Horgan ${ }^{9}$, D. W. Ming ${ }^{10}$, R. V. Morris ${ }^{10}$, S. M. Morrison ${ }^{8}$, E. B. Rampe ${ }^{10}$, N.

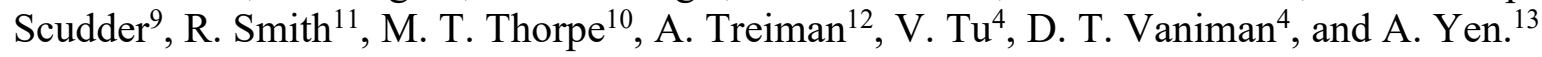 \\ ${ }^{3}$ Goddard Spaceflight Center, Greenbelt, MD; ${ }^{4}$ Planetary Science Institute, Tucson, AZ; \\ ${ }^{5}$ Chesapeake Energy, Oklahoma City, OK; ${ }^{6}$ NASA Ames Research Center, Moffett Field, CA; \\ ${ }^{7}$ Univ. of Arizona, Tucson, AZ; ${ }^{8}$ Carnegie Institution for Science, Washington, DC; ${ }^{9}$ Purdue \\ University; ${ }^{10}$ Johnson Spaceflight Center, Houston, TX; ${ }^{11}$ Stony Brook University ${ }^{12}$ Lunar and \\ Planetary Institute, Houston, TX; ${ }^{13}$ Jet Propulsion Laboratory, Pasadena, CA.
}




\section{In-Situ Mineralogical Analysis of the Venus Surface with X-ray Diffraction}

The Case for Scientific Exploration of the Venus Surface: Venus and Earth were likely formed from the same protoplanetary material, at a similar radial distance from the center of the solar nebula, and they had similar early histories. Venus should be Earth's twin, but present-day surface conditions on Venus are radically divergent from those of Earth. What events transpired to yield Venus and Earth end-members in the same solar system? Did conditions ever exist on Venus that could have fostered life? How and why did the evolutionary paths of Venus and Earth diverge? Moreover, what defines a habitable exoplanet? As an "Earthlike" planet in our solar system, Venus is an accessible surrogate for exoplanets detected in habitable zones around distant stars that diverge from what we consider "habitable."

Understanding Venus' surface mineralogy and evolution through direct measurements will inform comparative Terrestrial Planetology in our own solar system (the only one we can directly measure) and provide a basis for the interpretation of remote observations of "Venus-like" exoplanets planets circling sun-like stars ([1] and references therein).

The Importance of Mineralogical Analysis Using a Direct Crystallographic Technique (e.g., X-ray Diffraction) for Landed Venus Science: The history of a planet is written in its rocks and the minerals they contain. Because minerals are stable under known ranges of temperature, pressure and composition, a rock comprised of specific minerals can be used to identify the conditions under which it formed and subsequent environmental changes, based on individual mineral stability ranges and the presence or absence of equilibrium between them. More than elemental or isotopic analysis, definitive mineralogical analysis with X-ray Diffraction (XRD) provides information about habitability: T, P conditions of formation, present/past climate, water activity, the activity of biologically significant elements and the like. Such determinations are seldom possible if only qualitative mineralogical data are obtained or if the complete mineral assemblage is not characterized.

With regard to quantitative, definitive mineralogy, X-ray Diffraction - a direct crystallographic technique - is extraordinarily powerful and robust. For more than a century XRD has been the preferred method (indeed, the "gold standard") for mineralogical analysis of unknowns in terrestrial laboratories. Quantitative mineralogical results are obtained from XRD patterns using Rietveld refinement and other full-pattern fitting techniques [2-4]. Both crystalline and amorphous materials can be analyzed. Using XRD alone, all minerals present at $>3 \mathrm{wt} \%$ can be identified, quantified, and their elemental compositions determined or constrained. The amounts and valence states of all major elements, $\mathrm{H}$ and above (including the valences of those elements having several valence states, e.g., $\mathrm{Fe}$ ) can be determined directly from mineral formulae.

All other mineralogical analysis techniques ultimately rely on XRD for the definitive identification of unknown crystalline materials in their "training sets" or "fingerprint matching" routines.

Minerals are crystalline thermodynamic phases that have a unique structure and composition and that occur naturally. About 5,500 minerals have been described on Earth and their X-ray diffraction patterns and other characteristics are tabulated in the ICDD and RRUFF databases $[5,6]$ among others. About 400,000 additional inorganic compounds have been characterized by XRD and would be classified as minerals if they were found in a natural environment. There are many minerals yet undiscovered on Earth and likewise on Venus. 
A previously unknown mineral discovered on Venus by XRD can be fully characterized (both structure and, with SDD results described below, composition), and its significance to Venus' history understood, without recourse to other data. XRD is the principal means for identifying and characterizing minerals on Earth. XRD is the reference standard for all other mineralogical techniques.

The MSL-CheMin XRD: The first spacecraft capable crystallographic instrument:

The CheMin instrument on the MSL rover Curiosity [7] directly determines the mineralogy and elemental composition of powdered Martian regolith using XRD. In a complex sample such as a basalt, MSLCheMin can definitively identify and quantify all minerals present above $\sim 1$ wt. \%, establish or constrain their individual elemental compositions and quantify the amount of amorphous material present.

As the first crystallography instrument ever flown in space, MSLCheMin's mineralogical analyses have been critical to a number of first-of-theirkind achievements during its 8 year deployment on Mars. MSL-CheMin's third

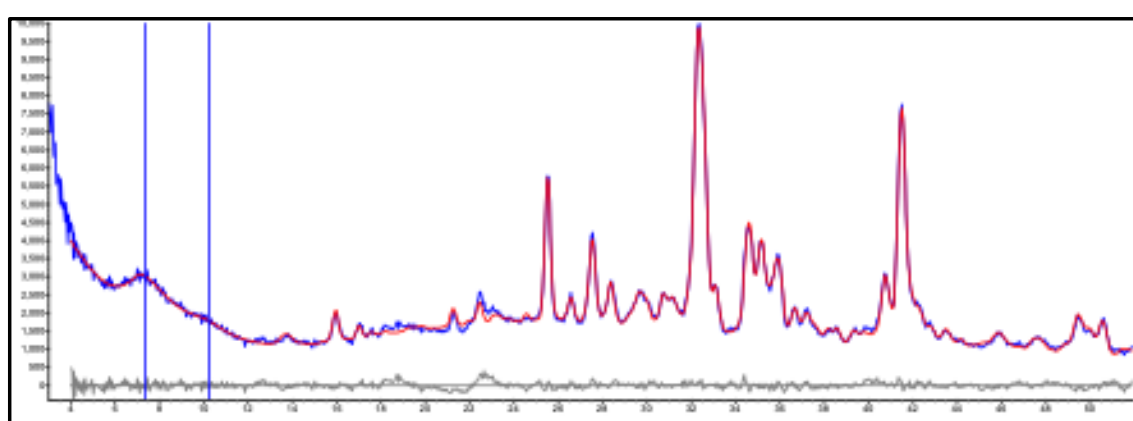

Fig. 1: CheMin XRD pattern of Cumberland. Blue = observed pattern, red = Rietveld refinement best fit, gray - least squares residual. Blue vertical lines denote 001 positions for clays.

Table 1. Mineral Abundances in the Cumberland Mudstone

\begin{tabular}{||l|c|l||}
\hline \multicolumn{1}{|c|}{ Mineral } & Wt.\% & \multicolumn{1}{c|}{ Composition } \\
\hline Plagioclase Feldspar $^{1}$ & $42.8(2)$ & $\mathrm{Ca}_{0.33(5)} \mathrm{Na}_{0.67(5)} \mathrm{Al}_{1.33} \mathrm{Si}_{2.67} \mathrm{O}_{8}$ \\
\hline Pigeonite $^{1}$ & $17.0(11)$ & $\mathrm{Mg}_{1.08(11)} \mathrm{Fe}_{0.78(16)} \mathrm{Ca}_{0.14(8)} \mathrm{Si}_{2} \mathrm{O}_{6}$ \\
\hline Orthopyroxene $^{1}$ & $14.5(8)$ & $\mathrm{Mg}_{0.83(8)} \mathrm{Fe}_{1.15(10)} \mathrm{Ca}_{0.02(5)} \mathrm{Si}_{2} \mathrm{O}_{6}$ \\
\hline Magnetite $^{2}$ & $11.5(4)$ & $\mathrm{Fe}_{2.81(5)} \quad 0.19 \mathrm{O}_{4}$ \\
\hline Sanidine $^{1,3}$ & $4.9(7)$ & $\mathrm{K}_{0.77(19)} \mathrm{Na}_{0.23} \mathrm{AlSi}_{3} \mathrm{O}_{8}$ \\
\hline Olivine $^{4}$ & 3.3 & $\left(\mathrm{FeMg}_{2} \mathrm{SiO}_{4}\right.$ \\
\hline Bassanite & 2.3 & $\mathrm{CaSO}_{4} .0 .5\left(\mathrm{H}_{2} \mathrm{O}\right)$ \\
\hline Akaganeite & 1.6 & $\mathrm{Fe}^{+3}\left(\mathrm{O}_{,} \mathrm{OH}, \mathrm{Cl}\right)$ \\
\hline Anhydrite & 1.3 & $\mathrm{CaSO}_{4}$ \\
\hline Hematite & 0.8 & $\mathrm{Fe}_{2} \mathrm{O}_{4}$ \\
\hline Total & $\mathbf{1 0 0 . 0}$ & \multicolumn{2}{|l|}{} \\
\hline
\end{tabular}

analysis, "Cumberland" is described here in its entirety to illustrate the power and unique capabilities of X-ray diffraction in characterizing complex mineral assemblages. Figure 1 and Tables 1-3 illustrate the data set obtained from this measurement and its interpretation.

Table 1 shows the mineral identifications and elemental compositions of major crystalline phases obtained through Rietveld refinement. In addition to determining mineral compositions, refined lattice parameters are also used to measure cation deficiency in

\begin{tabular}{|c|c|}
\hline Component & Wt. \% \\
\hline Crystalline Minerals & 51 \\
\hline Smectite Clay & 18 \\
\hline Amorphous Material & 31 \\
\hline Total & 100.0 \\
\hline
\end{tabular}


magnetite and the structural state of the potassium feldspar [8-9]. Clay minerals are identified and quantified using the FULLPAT method [3-4]. The position of the basal 001 clay mineral peaks (vertical blue lines in fig. 1) indicate that the clay mineral in Cumberland is a smectite. The position of the $02 \ell$ diffraction band of the smectite at $22.5^{\circ} 2 \theta$ indicates that it is Fe-rich and trioctahedral. The proportions of crystalline minerals, clay minerals and amorphous material (determined with FULLPAT) are shown in Table 2. The composition of the amorphous component is found by subtracting the crystalline composition from the overall composition determined by the Alpha Particle X-ray Spectrometer (APXS) on MSL (Table 3).

MSL-CheMin data are responsible for the first quantitative mineralogical analysis of the Mars soil [1011], the first identification and characterization of an ancient habitable environment on Mars [12-14], in concert with the Surface Analysis at Mars (SAM) instrument on MSL the first in situ radiometric dating of the Mars surface [15], the establishment of a maximum

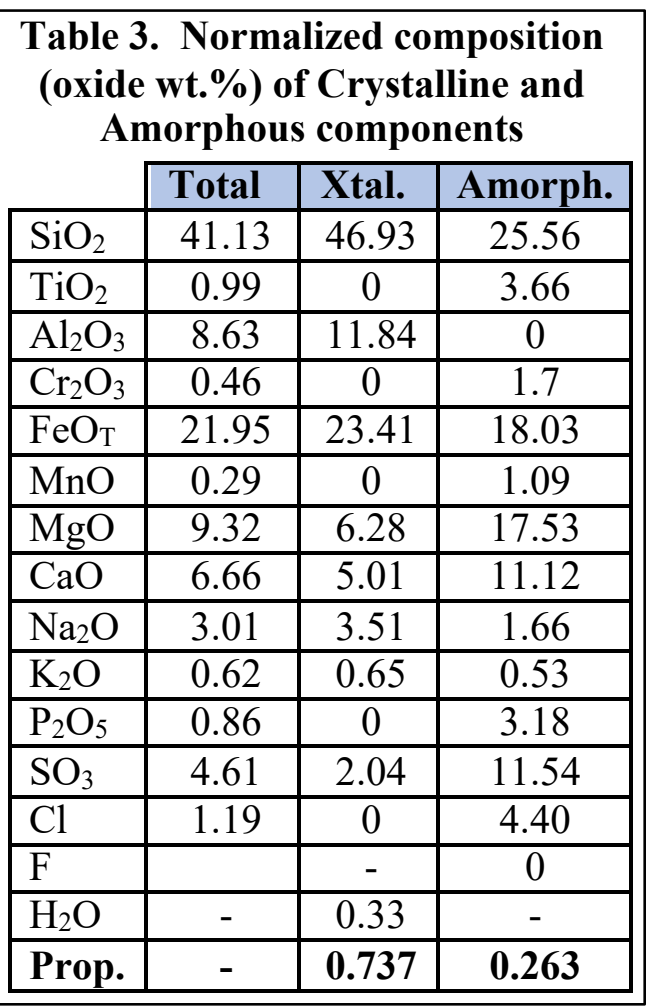
limit on the $\mathrm{CO}_{2}$ content of the Mars atmosphere in Hesperian time [16], the first direct evidence of silicic volcanism on Mars [17], the first ground-truth mineralogy of orbital spectral measurements [18], and the first in situ evidence of the gradual drying out and oxidation of the Gale crater environment (and by proxy the early Mars atmosphere) [19]. All of MSL-CheMin's mineralogical analyses have been of basaltic soils, sandstones and mudstones and their alteration products, similar to mineralogies expected on Venus. The methodology by which refined lattice parameters are converted from a mineral into its elemental composition, and elemental compositions for the first 5 years of analyses performed by MSL-CheMin in Gale crater are shown in $[8,9]$. All raw and reduced data records, analyses by the MSL-CheMin Science team, and open access papers describing the mineralogical results and their interpretation can be found in the MSL-CheMin database [20], in the Geosciences node of the Planetary Data System, and are summarized in a recent review of MSL-CheMin's first 6 years on Mars [21].

As summarized by Velbel in a "Highlights and Breakthroughs" article in American Mineralogist (“Crystallography: Curiosity's Bragging Right”) [22]:

“....The mineral abundances and compositions determined from MSL Curiosity CheMin data are the most complete mineralogical data set for Mars surface materials until a Mars Sample Return mission (MSR) which is still at least a decade away."

The Honeybee Robotics Venus Drill: A prototype drill intended for use on a Venus lander has already been developed and tested in JPL's Venus chamber. It has successfully drilled in 120 MPa Saddleback basalt under Venus conditions [23]. Fig. 2 shows the HBR drill acquiring a sample from Saddleback Basalt under Venus surface conditions. More than $90 \%$ of the drilled material has a particle size $<150 \mu \mathrm{m}$, suitable for analysis by a MSL-CheMin-like transmission geometry instrument without sieving. 


The CheMinV Instrument
Intended for Landed Venus Science:
Like MSL-CheMin, CheMinV is a
powder XRD instrument utilizing
transmission Debye-Sherrer geometry,
broutht into practice more than a
century ago. Unlike MSL-CheMin,
which utilizes X-ray Fluorescence data
from APXS (a companion instrument
on the rover), CheMinV will utilize a
Silicon Drift Detector (SDD) integral
to the instrument to determine the
chemical composition of the exact
sample used for diffraction analysis. It
is important to note that the major
element chemistry of every mineral in the sample is determined using XRD data alone. XRF is only required to quantify minor or trace elements which are not reflected in the lattice parameter measurements or to aid in fully populating atoms in an XRD-determined structure should a completely new mineral be discovered.

MSL-CheMin's analyses on Mars are conducted over multiple Mars nights, integrating data for 20-30 hours (high-quality data have been obtained from analyses of only 2 hours, e.g., [17]). On Venus, where surface temperatures exceed $500^{\circ} \mathrm{C}$, the lifetime of a lander is only a few hours, during which time drilling, sample delivery, multiple sample analyses and data transmission must be completed. CheMinV is the product of a decade of post-CheMin technology development, yielding a $>10 \mathrm{X}$ increase in data acquisition speed, a 50\% reduction in instrument mass and volume and improved pattern resolution. X-ray Diffraction analyses of drilled and powdered samples on Venus by CheMinV will yield:

- Identification of all minerals present $>1 \mathrm{wt}$. \%.

- Quantification of all minerals present $>3 \mathrm{wt}$. \%, including their structure states and cation occupancies.

- Abundance of all major elements present in each mineral ( $\mathrm{H}$ and above) from their refined lattice parameters, for minerals present at $>5 \mathrm{wt} . \%$

- Valence state of all major elements, including speciation of mult-valent species such as Fe for minerals present at $>3 \mathrm{wt} \%$ (from their empirical formulas).

There are no spacecraft instruments currently in NASA's planetary science inventory that can claim even one of these capabilities.

Fig. 3 shows the geometry of the CheMinV instrument. An X-ray tube operated at $25 \mathrm{keV}$ and $200 \mu \mathrm{A}$ illuminates a pinhole aperture centered on a transmission geometry sample cell. An X-ray sensitive Charge Coupled Device (CCD) imager records the diffraction pattern from the sample. A SDD detector collects compositional data from the sample. As noted above, the SDD analysis will be used to detect minor or trace elements not identifiable through lattice parameter measurements.

Quantitative Mineralogical Analysis with Terra: Terra, a commercial spinoff of the CheMin instrument that is used throughout the world in the petrochemical, minerals, art 
conservation and pharmaceutical industries, has a nearly identical diffraction geometry to CheMinV. A $~ 100 \mathrm{mg}$ sample of powdered Saddleback Basalt drilled and collected under Venus surface conditions was analyzed in Terra for 15 minutes, then reanalyzed for 8 hours in a commercial Rigaku laboratory Xray Diffractometer.

Table 4 shows the resulting Rietveld refinement and quantitative analysis from Terra, compared to that of the Rigaku instrument. Compositions (formulae) for minerals having variable chemistry are derived from the refined lattice parameters (i.e., andesine, augite, pigeonite and forsterite) from the Terra instrument. CheMinV will provide datasets equivalent to that shown in Fig. 1 and Tables 1-4, in $\sim 1$ hour (nominal). Integration for less than an hour will still result in a quantitative result, but increased precision, accuracy and detection limits come with increased analysis time. Additional samples are analyzed by rotating the sample wheel to a pristine sample cell. As many as 4 analyses are possible with this design.

All major components of the CheMinV (High Voltage Power Supply (HVPS), X-ray tube, Camera and Instrument Control Electronics and SDD electronics will be built to TRL6 under NASA's MatISSE and DALI instrument programs by the end of PY 2021. The Amptek SDD detector and e2v CCD30-11 CCD detector are flight qualified from earlier missions.

\begin{tabular}{|c|c|c|c|}
\hline \multicolumn{2}{|c|}{$\begin{array}{l}\text { Table 4. Mineral Abundances in } \\
\text { Saddleback Basalt drilled using the HBR } \\
\text { Venus Drill }\end{array}$} & \multirow{2}{*}{$\begin{array}{c}\text { Terra } \\
15 \text { minutes } \\
\text { (wt. \%) }\end{array}$} & \multirow{2}{*}{$\begin{array}{l}\text { Rigaku } \\
8 \text { hours } \\
\text { (wt. \%) }\end{array}$} \\
\hline Mineral & Formula & & \\
\hline Andesine 1,2 & $\mathrm{Ca}_{0.31} \mathrm{Na}_{0.62}\left(\mathrm{Al}_{0.735} \mathrm{Si}_{3.265}\right) \mathrm{O}_{8}$ & 72 & 69 \\
\hline Augite $^{1}$ & $\mathrm{Mg}_{1.1} \mathrm{Fe}_{0.73} \mathrm{Ca}_{0.17} \mathrm{Si}_{2} \mathrm{O}_{6}$ & 14 & 14 \\
\hline Pigeonite $^{1}$ & $\left(\mathrm{Mg}_{0.78} \mathrm{Fe}_{1.04} \mathrm{Ca}_{0.18}\right) \mathrm{Si}_{2} \mathrm{O}_{6}$ & 5 & 6 \\
\hline Olivine $^{1}$ & $\left(\mathrm{Mg}_{0.98} \mathrm{Fe}_{1.02}\right) \mathrm{SiO}_{4}$ & 2 & 2 \\
\hline Hematite & $\mathrm{Fe}_{2} \mathrm{O}_{3}$ & & \\
\hline \multicolumn{2}{|l|}{ Total } & 101 & 99 \\
\hline
\end{tabular}

Quantitative and definitive mineralogy are critical for elucidating the early history and evolution of Venus, for comparative planetology of the rocky planets, for deducing potential habitability on early Venus, and for characterizing Venus as a surrogate for Venus-like exoplanets. These mineralogical capabilities have already been demonstrated by MSL-CheMin during its 8 year deployment on Mars. The CheMinV instrument is a next-generation instrument, benefiting from 15 years of post MSL-CheMin improvements, modified for the particular requirements of a Venus landed mission. 
CheMinV meets or exceeds the requirements of six investigations described in the recent Venus Goals, Objecties and Investigations document (1) that pertain to measurements of Venus surface chemistry and mineralogy (Table 6).

\section{Table 6. Venus GOI and Recommended Measurements [1]}

\begin{tabular}{|c|c|c|c|}
\hline Goal & Objective & Investigation & Measurement \\
\hline \multirow[t]{2}{*}{$\begin{array}{l}\text { I. } \\
\text { Understand Venus' } \\
\text { early evolution and } \\
\text { potential habitability to } \\
\text { constrain the evolution } \\
\text { of Venus-size } \\
\text { (exo)planets. }\end{array}$} & \multirow[t]{2}{*}{$\begin{array}{l}\text { A. } \\
\text { Temperate } \\
\text { surface } \\
\text { conditions and } \\
\text { liquid water at } \\
\text { early times? }\end{array}$} & $\begin{array}{l}\text { HO. Hydrous Origins: (1). } \\
\text { Evidence for abundant silicic } \\
\text { rocks and/or ancient } \\
\text { sedimentary rocks. }\end{array}$ & $\begin{array}{l}\text { Identification of granitic rocks (suggested } \\
\text { for some tesserae), sedimentary rocks } \\
\text { formed with liquid water such as sulfates } \\
\text { and halides (e.g., evaporites), silica (e.g., in } \\
\text { hot springs or hardpans), or carbonates. } \\
\text { Chemical analysis using XRF, detailed } \\
\text { mineralogic composition. }\end{array}$ \\
\hline & & $\begin{array}{l}\text { RE. Recycling (1): } \\
\text { Search for structural, } \\
\text { geomorphic and chemical } \\
\text { evidence of crustal recycling. }\end{array}$ & $\begin{array}{l}\text { Identification of } \mathrm{Si}-\mathrm{Al} \text { crustal minerals. } \\
\text { Detection of chemical evidence of recycling } \\
\text { (enrichment or depletion of incompatible } \\
\text { elements such as K, P, Zr), Si abundance. }\end{array}$ \\
\hline \multirow{4}{*}{$\begin{array}{l}\text { III. } \\
\text { Understand the } \\
\text { geological history } \\
\text { preserved on the } \\
\text { surface of Venus and } \\
\text { the present-day } \\
\text { couplings between the } \\
\text { surface and } \\
\text { atmosphere. }\end{array}$} & $\begin{array}{l}\text { A. } \\
\text { What geologic } \\
\text { processes have } \\
\text { shaped the } \\
\text { surface of } \\
\text { Venus? }\end{array}$ & $\begin{array}{l}\text { GC. Geochemistry (1): } \\
\text { Determine elemental } \\
\text { chemistry, mineralogy and } \\
\text { rock types at localities } \\
\text { representative of global } \\
\text { geologic units on Venus }\end{array}$ & $\begin{array}{l}\text { Characterization of Venus surface chemistry } \\
\text { and mineralogy. Measurement of major } \\
\text { elements } 11 \leq \mathrm{Z} \leq 92 \text {, critical minor and } \\
\text { trace elements like } \mathrm{Cr} \text { and Ni. Identification } \\
\text { of rock types that may indicate igneous } \\
\text { provenance. }\end{array}$ \\
\hline & \multirow[t]{3}{*}{$\begin{array}{l}\text { B. } \\
\text { How do the } \\
\text { atmosphere and } \\
\text { surface of } \\
\text { Venus react? }\end{array}$} & $\begin{array}{l}\text { LW. Local Weathering (1): } \\
\text { Evaluate the mineralogy, } \\
\text { oxidation state, and changes in } \\
\text { chemistry of surface- } \\
\text { weathered rock exteriors at } \\
\text { localities representative of } \\
\text { global geologic units on } \\
\text { Venus }\end{array}$ & $\begin{array}{l}\text { Identification of oxidized primary igneous } \\
\text { minerals such as Fe-oxides (magnetite and } \\
\text { hematite). Identification of anhydrous salt } \\
\text { minerals such as anhydrite as well as other } \\
\text { basaltic alteration phases. Determination } \\
\text { of basaltic alteration as a function of depth } \\
\text { and underlying mineralogy. }\end{array}$ \\
\hline & & $\begin{array}{l}\text { GW. Global Weathering } \\
\text { (2). Determine the causes and } \\
\text { spatial extents of global } \\
\text { weathering regimes on Venus }\end{array}$ & $\begin{array}{l}\text { Discrimination of key rock types (e.g., } \\
\text { basalt vs. granite), determination of } \\
\text { minerals responsible for radar backscatter } \\
\text { variations (magnetite, hematite, pyrite), } \\
\text { determination of surface mineralogy and Fe } \\
\text { oxidation state. }\end{array}$ \\
\hline & & $\begin{array}{l}\text { CI. Chemical Interactions } \\
\text { (3): Characterize atmospheric } \\
\text { composition and chemical } \\
\text { gradients from the surface to } \\
\text { the cloud base both at key } \\
\text { locations and globally. }\end{array}$ & $\begin{array}{l}\text { Identification of surface materials enriched } \\
\text { in } \mathrm{S} \text { relative to Earth basalts, atmospheric } \\
\text { reaction of } \mathrm{SO}_{3} \text { with Ca-bearing silicates to } \\
\text { form } \mathrm{CaSO}_{4} \text { (anhydrite). Identification of } \\
\mathrm{Cl} \text {-bearing phosphate phases, } \\
\text { presence/absence of hydroxy-bearing } \\
\text { igneous minerals (e.g., amphibole or biotite) } \\
\text { or products of their decomposition. }\end{array}$ \\
\hline
\end{tabular}

\section{References:}

[1]. Scientific Goals, Objectives and Investigations or Venus Exploration (2019).

[2]. Bish, D.L., and J. E. Post (1993). Am. Min., 78, 932-940.

[3] Chipera, S. J. and D. L. Bish (2002). J. Applied Crystallography 35, 744-749.

[4]. Chipera, S., \& Bish, D. (2013). Advances in Materials Physics and Chemistry, 3(01), 47. 
[5] Lafuente, B, Downs, R, Yang, H, Stone, N (2015). In: Highlights in Mineralogical Crystallography, T Armbruster and R Danisi, eds. Berlin, Germany, W. De Gruyter, p.1-30.

[6] International Center for Diffraction Data, PDF-2 Minerals database.

[7] Blake, D.F., et al. (2012). Space Sci. Rev. 170:341-399, DOI 10.1007/s11214-012-9905-1.

[8]. Morrison, S.M., et al. (2018a). American Mineralogist. DOI: 10.2138/am-2018-6123.

[9]. Morrison, S.M., et al. (2018b). American Mineralogist. DOI: 10.2138/am-2018-6124.

[10]. Blake, D.F., et al. (2013). Science, 341, 1239505; doi: 10.1126/science.1239505.

[11]. Bish, D.L., et al. (2013). Science, 341, 1238932; doi: 10.1126/science.1238932.

[12]. Vaniman, D.T., et al. (2014). Science, 10.1126/science.1243480.

[13]. Grotzinger, John P. et al (2013). Science, 10.1126/science.1242777.

[14]. Bristow, T. F., et al. (2015). Am. Min. Vol. 100, pages 824-836, doi.org/10.2138/am-2015.

[15]. Farley, K. A., et al. (2013). Science 343(6169) DOI: 10.1126/science.124166.

[16]. Bristow,T. F., et al. (2017). www.pnas.org/cgi/doi/10.1073/ pnas.1616649114.

[17]. Morris, R.V., et al. (2016). PNAS: doi: 10.1073/pnas.1607098113.

[18]. Achilles, C.N., et al. (2017). J. Geophys. Res. Planets, 122, doi:10.1002/2017JE005262.

[19]. Bristow, T.F., et al. (2018). Science Advances, Sci. Adv. 2018;4: eaar3330.

[20]. http://odr.io/CheMin

[21]. Rampe, E.B., et al. and the MSL Science Team (2020). Geochemistry, Vol. 80, Issue 2, 125605 https://doi.org/10.1016/j.chemer.2020.125605.

[22]. Velbel, M.A. (2018). DOI: http://doi.org/10.2138/am-2018-6468CCBYNCND.

[23]. Zacny, K. et al. (2017). IEEE Aerospace Conference, Big Sky MT, 2017. 